\title{
Tert-butyl esters of 2,3-diaryl-3-arylaminopropanoic acids - stereoselective synthesis, isolation, spectroscopic and structural elucidation
}

\author{
Donka N. Tasheva, Sonya Y. Zareva* \\ University of Sofia "St. Kl. Ohridski", Faculty of Chemistry, Sofia 1164, Bulgaria \\ *Corresponding author: e-mail: ahsz@chem.uni-sofia.bg
}

\begin{abstract}
A series of seven substituted tert-butyl esters of 2,3-diaryl-3-arylaminopropanoic acids has been synthesized, isolated, spectroscopically and structurally elucidated. An influence of the substituents on the spectroscopic characteristics and conformations is discussed using the data of the linear-polarized IR- (IR-LD), UV-spectroscopy and ${ }^{1} \mathrm{H}-\mathrm{NMR}$. Theoretical quantum chemical calculations are carried out, with a view to explaining and supporting the experimental optical properties and the electronic structure. The stereoselective synthesis of the corresponding diastereoisomers is optimized, thus giving good yields (62-72\%) and purity of the compounds
\end{abstract}

Keywords: tert-butyl esters of 2,3-diaryl-3-arylaminopropanoic acids, optical properties, quantum chemistry.

\section{INTRODUCTION}

The design of novel substituted $\beta$-amino acid derivatives is still interesting for organic chemistry due to their biologically important properties and the occurrence in natural products ${ }^{1-3}$. The stereoselective synthesis and optimization of the synthetic pathway for the obtaining of the pure diastereoisomers in good yields is an important key for the preparation of these compounds which are useful as building blocks for $\beta$-lactams ${ }^{4-8}$ and peptides, containing $\beta$-amino acids ${ }^{4,6}$. Herein we report the synthesis, isolation, spectroscopic and structural elucidation of seven substituted tert-butyl esters of 2,3-diaryl-3-arylaminopropanoic acids, depicted and numbered in Scheme 1. The optimized synthetic pathway results to formation of the pure diastereoisomers. The optical properties of the compounds (1)-(7), are fully characterized both theoretically and experimentally by means of the polarized IR- and UVspectroscopy, as well as quantum chemical ab initio and DFT calculations. In addition ${ }^{1} \mathrm{H}$-NMR measurements are applied.

\section{EXPERIMENTAL}

\section{Materials and methods}

The IR-spectra were measured on a Thermo Nicolet FTIR-spectrometer $\left(4000-400 \mathrm{~cm}^{-1}, 2 \mathrm{~cm}^{-1}\right.$ resolution, 200 scans) equipped with a Specac wire-grid polarizer. Nonpolarized solid-state IR spectra were recorded using the $\mathrm{KBr}$ pellets technique. The oriented samples were obtained as a suspension in a nematic liquid crystal (MLC 6815, Merck) with the presence of an isolated nitrile stretching IR-band at about $2245 \mathrm{~cm}^{-1}$ additionally serving as an orientation indicator ${ }^{9-17}$.

Ultraviolet (UV-) spectra were recorded on Tecan Safire Absorbance/Fluorescence XFluor 4 V 4.40 spectrophotometer operating between 190 and $900 \mathrm{~nm}$, using solvent ethanol (Uvasol, Merck product) at a concentration of $2.5 .10^{-5} \mathrm{M}$ in $0.921 \mathrm{~cm}$ quarz cells.

The elemental analysis was carried out according to the standard procedures for $\mathrm{C}$ and $\mathrm{H}\left(\right.$ as $\mathrm{CO}_{2}$, and $\left.\mathrm{H}_{2} \mathrm{O}\right)$ and $\mathrm{N}$ (by the Dumas method).

The melting points were measured on Kofler apparatus and were uncorrected. The TLC was performed on the plates of Silica Gel 60 (Merck) with hexane: acetone (6:1) as a mobile phase.

${ }^{1} H$ NMR-Spectra were recorded on Avance DRX 250 spectrometer $(250 \mathrm{MHz})$. Chemical shifts are reported relative to TMS as an internal standard.

Quantum chemical calculations are performed with the GAUSSIAN 98 and Dalton 2.0 program packages ${ }^{\mathbf{1 8 , 1 9}}$. The geometries of (1)-(7) are optimized at density functional theory (DFT) using the $6-311++\mathrm{G}^{* *}$ basis set. The DFT method employed is B3LYP, which combines Backe's threeparameter non-local exchange function with the correlation function of Lee, Yang and Parr ${ }^{20-22}$. Molecular geometries of the studied species are fully optimized by the force gradient method using Berny algorithm. For every structure, the stationary points found on the molecule potential energy hypersurfaces are characterized using standard analytical harmonic vibrational analysis. The absence of the imaginary frequencies, as well as of the negative eigenvalues of the second-derivative matrix, confirmed that the stationary points correspond to the minima of the potential energy hypersurfaces. The calculated vibrational frequencies and infrared intensities are checked to establish which kind of performed calculations are in the best agreement with the experimental data. The DFT method provides accurate vibrational data, as far as the calculated standard deviations of less then $8 \mathrm{~cm}^{-1}$ are concerned, which correspond to groups, not participating in significant intra- or intermolecular interactions. A modification of the results using the empirical scaling factor 0.9614 is done to achieve better correspondence between the experimental and theoretical values $^{23,24}$. TD DFT and CIS calculations are performed for elucidation of the theoretical optical properties of the seven compounds in solution. The theoretical approach is described in ${ }^{9-17}$.

\section{Synthesis}

Preliminary experiments ${ }^{25}$ for the optimization of the reaction of tert-butyl phenylacetate and benzylideneaniline revealed that good yields and stereoselectivity for the product (1) was obtained by performing the reaction in PTC (phase-transfer catalysis) conditions. The compounds (1)(7) were prepared according to the following procedure: Aqueous sodium hydroxide $(50 \%, 5 \mathrm{~mL})$ is added to the magnetically stirred solution of tert-butyl phenylacetate (10 
mmol) and the corresponding arylmethylideneaniline (Schiff base $)(10 \mathrm{mmol})$ in $5 \mathrm{~mL} \quad \mathrm{CH}_{3} \mathrm{CN}$, using benzyltriethylammonium chloride (TEBA) $(0.5 \mathrm{mmol})$ as a PTC. Thus prepared acetonitrile solutions are stirred at room temperature for $1 \mathrm{~h}$ (for compounds $1,3-7$ ) or $24 \mathrm{~h}$ (for compound 2). Water $(50 \mathrm{~mL})$ was added and the solid was collected and washed with water to the neutral. The following diastereomeric ratios were observed $\left({ }^{1} \mathrm{H} \mathrm{NMR}\right)$ for the crude products (erythro/threo ratio is 85:15 for compounds 1, 3 and 5; 95:5 for 4, 6, 7 and 15:85 for compound 2). After recrystallization the main diastereoisomers of the products (1)-(7) were isolated with $62-72 \%$ yields. The configuration of the isolated diastereoisomers is determined, using their ${ }^{1} \mathrm{H}-\mathrm{NMR}$ spectra and literature data ${ }^{\mathbf{2 6}}$ for the similar compounds.

erythro-(1): m.p. ${ }^{186}-188^{\circ} \mathrm{C}$ (benzene/hexane); Yield $70 \%$; found $\mathrm{C}, 80.39 \%, \mathrm{H}, 7.50 \%, \mathrm{~N}, 3.75 \%$; calcd. $\left[\mathrm{C}_{25} \mathrm{H}_{27} \mathrm{NO}_{2}\right], \mathrm{C}, 80.40 \%, \mathrm{H}, 7.29 \%, \mathrm{~N}, 3.75 \% .{ }^{1} \mathrm{H}-\mathrm{NMR}$ $\left(\mathrm{CDCl}_{3}\right): 1.18(\mathrm{~s}, 9 \mathrm{H}), 3.77(\mathrm{~d}, 1 \mathrm{H}, \mathrm{J}=10.1 \mathrm{~Hz}), 4.88(\mathrm{~d}$, $1 \mathrm{H}, \mathrm{J}=10.1 \mathrm{~Hz}), 6.39(\mathrm{~d}, 2 \mathrm{H}) ; 6.59(\mathrm{t}, 1 \mathrm{H}), 6.98(\mathrm{t}, 2 \mathrm{H})$, 7.16-7.51 (m, 10H); threo-(2): m.p. $144-146^{\circ} \mathrm{C}$ (ethanol); Yield 44\%; found C, $80.51 \%, \mathrm{H}, 7.42 \%, \mathrm{~N}, 3.87 \%$; calcd. $\left[\mathrm{C}_{26} \mathrm{H}_{29} \mathrm{NO}_{2}\right], \mathrm{C}, 80.59 \%, \mathrm{H}, 7.54 \%, \mathrm{~N}, 3.61 \%$. ${ }^{1} \mathrm{H}-\mathrm{NMR}$ $\left(\mathrm{CDCl}_{3}\right): 1.34(\mathrm{~s}, 9 \mathrm{H}), 2.24(\mathrm{~s}, 3 \mathrm{H}), 3.93(\mathrm{~d}, 1 \mathrm{H}, \mathrm{J}=6.9$ $\mathrm{Hz}), 4.88$ (d, 1H, J = $6.9 \mathrm{~Hz}), 5.09$ (br s, 1H), 6.32 (d, $2 \mathrm{H}), 6.53(\mathrm{~d}, 1 \mathrm{H}), 6.88(\mathrm{~d}, 1 \mathrm{H}), 7.00(\mathrm{~d}, 1 \mathrm{H}), 7.13-7.6(\mathrm{~m}$, $10 \mathrm{H})$; erythro-(3): m.p. $149-151^{\circ} \mathrm{C}$ (ethanol/ethyl acetate); Yield $66 \%$; found C, $80.85 \%, \mathrm{H}, 7.28 \%$, N, 3.71\%; calcd. $\left[\mathrm{C}_{26} \mathrm{H}_{29} \mathrm{NO}_{2}\right], \mathrm{C}, 80.59 \%, \mathrm{H}, 7.54 \%, \mathrm{~N}, 3.61 \%$. ${ }^{1} \mathrm{H}-\mathrm{NMR}$ $\left(\mathrm{CDCl}_{3}\right): 1.18(\mathrm{~s}, 9 \mathrm{H}), 2.12(\mathrm{~s}, 3 \mathrm{H}), 3.76(\mathrm{~d}, 1 \mathrm{H}, \mathrm{J}=10.1$ $\mathrm{Hz}$ ), 3.83 (br s, 1H, 4.87), (d, 1H, J = $10.1 \mathrm{~Hz}$ ), 6.19 (d, $2 \mathrm{H}), 6.41(\mathrm{~d}, 1 \mathrm{H}), 6.87(\mathrm{t}, 1 \mathrm{H}), 7.23-7.55(\mathrm{~m}, 10 \mathrm{H})$; erythro(4): m.p. $160-162^{\circ} \mathrm{C}$ (hexane); Yield $63 \%$; Found $\mathrm{C}$, $80.83 \%, \mathrm{H}, 7.36 \%, \mathrm{~N}, 3.61 \%$; calcd. $\left[\mathrm{C}_{26} \mathrm{H}_{29} \mathrm{NO}_{2}\right], \mathrm{C}$, $80.59 \%, \mathrm{H}, 7.54 \%, \mathrm{~N}, 3.61 \% .{ }^{1} \mathrm{H}-\mathrm{NMR}: 1.18$ (s, 9H), 2.12 (s, 3H), $3.76(\mathrm{~d}, 1 \mathrm{H}, \mathrm{d}=10.1 \mathrm{~Hz}), 4.84(\mathrm{~d}, 1 \mathrm{H}, \mathrm{J}=10.1$ $\mathrm{Hz}), 6.30(\mathrm{~d}, 2 \mathrm{H}), 6.79(\mathrm{~d}, 2 \mathrm{H}), 7.4-7.50(\mathrm{~m}, 10 \mathrm{H})$; erythro(5): m.p. $150-152^{\circ} \mathrm{C}$ (ethanol/ethyl acetate); Yield $62 \%$; Found C, 73.82\%, H, 6.11\%, N, 3.70\%; calcd. $\left[\mathrm{C}_{25} \mathrm{H}_{26} \mathrm{ClNO}_{2}\right], \mathrm{C}, 73.61 \%, \mathrm{H}, 6.42 \%, \mathrm{~N}, 3.43 \% .{ }^{1} \mathrm{H}-\mathrm{NMR}$ $\left(\mathrm{CDCl}_{3}\right): 1.22(\mathrm{~s}, 9 \mathrm{H}), 3.85(\mathrm{~d}, 1 \mathrm{H}, \mathrm{J}=9.7 \mathrm{~Hz}), 4.65(\mathrm{~d}$,
$\mathrm{J}=4.2 \mathrm{~Hz}), 4.90\left(\mathrm{dd}, 1 \mathrm{H}, \mathrm{J}_{1}=9.7 \mathrm{~Hz}, \mathrm{~J}_{2}=4.3 \mathrm{~Hz}\right), 6.41$ $(\mathrm{dd}, 1 \mathrm{H}), 6.49(\mathrm{dt}, 1 \mathrm{H}), 6.88(\mathrm{dt}, 1 \mathrm{H}), 7.09(\mathrm{dd}, 1 \mathrm{H}), 7.24-$ 7.48 (m, 10H); erythro-(6): m.p. $157-159^{\circ} \mathrm{C}$ (ethanol/ethyl acetate); Yield $71 \%$; found $\mathrm{C}, 73.86 \%, \mathrm{H}, 6.61 \%, \mathrm{~N}, 3.50 \%$; calcd. $\left[\mathrm{C}_{25} \mathrm{H}_{26} \mathrm{ClNO}_{2}\right], \mathrm{C}, 73.61 \%, \mathrm{H}, 6.42 \%, \mathrm{~N}, 3.43 \%$. ${ }^{1} \mathrm{H}-\mathrm{NMR}\left(\mathrm{CDCl}_{3}\right): 1.19(\mathrm{~s}, 9 \mathrm{H}), 3.76(\mathrm{~d}, 1 \mathrm{H}, \mathrm{J}=10.0 \mathrm{~Hz})$, 3.96 (br s, 1H), 4.87 (dd, J $\left.=10.0 \mathrm{~Hz}, \mathrm{~J}_{2}=4.1 \mathrm{~Hz}\right), 6.25$ $(\mathrm{dd}, 1 \mathrm{H}), 6.37(\mathrm{t}, 1 \mathrm{H}), 6.55(\mathrm{dd}, 1 \mathrm{H}), 6.88(\mathrm{t}, 1 \mathrm{H}), 7.22-$ $7.47(\mathrm{~m}, 10 \mathrm{H})$; erythro-(7): m.p. $154-156^{\circ} \mathrm{C}$ (hexane); Yield $71 \%$; found $\mathrm{C}, 73.87 \%, \mathrm{H}, 6.13 \%, \mathrm{~N}, 3.43 \%$; calcd. $\left[\mathrm{C}_{25} \mathrm{H}_{26} \mathrm{ClNO}_{2}\right], \mathrm{C}, 73.61 \%, \mathrm{H}, 6.42 \%, \mathrm{~N}, 3.43 \% .{ }^{1} \mathrm{H}-\mathrm{NMR}$ $\left(\mathrm{CDCl}_{3}\right): 1.19(\mathrm{~s}, 9 \mathrm{H}), 3.76(\mathrm{~d}, 1 \mathrm{H}, \mathrm{J}=10.0 \mathrm{~Hz}), 3.91$ (br s, $1 \mathrm{H}), 4.84(\mathrm{~d}, \mathrm{~J}=10.0 \mathrm{~Hz}), 6.31(\mathrm{~d}, 2 \mathrm{H}), 6.93(\mathrm{~d}, 2 \mathrm{H})$, $7.25-7.47(\mathrm{~m}, 10 \mathrm{H})$.

\section{RESULT AND DISCUSSION}

The performed conformational analysis is carried out by the variation of the dihedral angles $\phi 1-\phi 3$ (Scheme 1). The potential energy surphases show series of conformational minima are obtained with the energy values $E$ less than 0.5 $\mathrm{kJ} / \mathrm{mol}$.

The theoretical geometry parameters and the most stable form are compared with the available crystallographic data of the derivatives of 3-hydroxy-2,3-diphenylpropanoic $\operatorname{acid}^{27,28}$. The main difference is obtained comparing the dihedral -N-C-C-C(O)- angle values show a difference of $2.1^{\circ}$, thus indicating an excellent correlation between the theoretical and experimental geometry parameters. The obtained $\mathrm{z}=2$ proposed a Davydov splitting effect of corresponding IR-spectra in crystaline state of pairs of maxima with different polarization according to the theoretical background in ${ }^{9-17}$. The group theory proposed a close to the co-linear orientation of the $\bar{v}_{\mathrm{NH}}$ and $\bar{v}_{\mathrm{C}=\mathrm{O}}$ in the frame of the isolated molecule of (2) as well as in the frame of the unit cell. The corresponding dihedral angle of both transition moments is $11.2(4)^{\circ}$. In contrast the out-ofplane vibrations of the aromatic fragments would be eliminated at a different dichroic ratios.

The IR-spectroscopic elucidation of the pure diastereoisomers in the solid-state (Fig. 1) is obtained by means of the Linear-dichroic infrared (IR-LD) spectroscopic

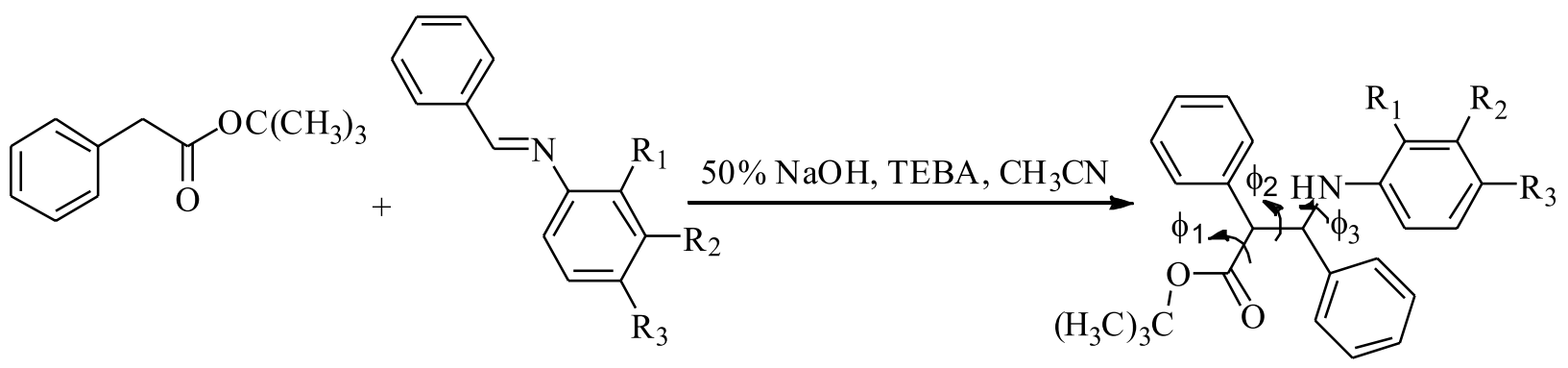

$$
\begin{aligned}
& \mathrm{R}_{1}=\mathrm{R}_{2}=\mathrm{R}_{3}=\mathrm{H}(\mathbf{1}) ; \\
& \mathrm{R}_{1}=\mathrm{CH}_{3}, \mathrm{R}_{2}=\mathrm{R}_{3}=\mathrm{H}(\mathbf{2}) ; \\
& \mathrm{R}_{2}=\mathrm{CH}_{3}, \mathrm{R}_{1}=\mathrm{R}_{3}=\mathrm{H}(\mathbf{3}) ; \\
& \mathrm{R}_{3}=\mathrm{CH}_{3}, \mathrm{R}_{1}=\mathrm{R}_{2}=\mathrm{H}(\mathbf{4}) ; \\
& \mathrm{R}_{1}=\mathrm{Cl}, \mathrm{R}_{2}=\mathrm{R}_{3}=\mathrm{H}(\mathbf{5}) ; \\
& \mathrm{R}_{2}=\mathrm{Cl}, \mathrm{R}_{1}=\mathrm{R}_{2}=\mathrm{H}(\mathbf{6}) ; \\
& \mathrm{R}_{3}=\mathrm{Cl}, \mathrm{R}_{1}=\mathrm{R}_{2}=\mathrm{H}(\mathbf{7})
\end{aligned}
$$




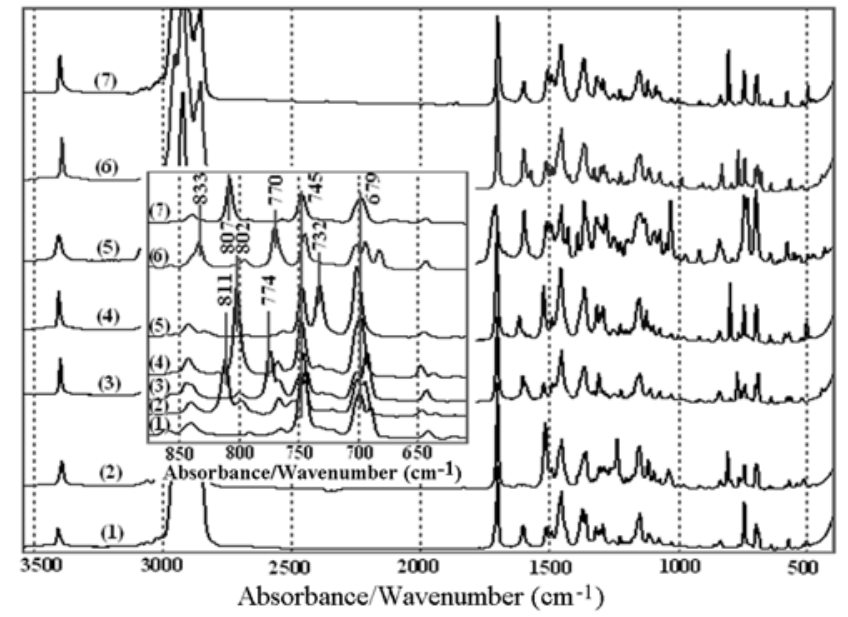

Figure 1. IR-spectra of (1)-(7) in solid-state in $\mathrm{KBr}$ pellets; The corresponding IR-spectroscopic region within $900-600 \mathrm{~cm}^{-1}$ shown in the small figure

measurements. The application of the reducing-difference procedure result to the experimental IR-assignment of the spectroscopic characteristics. The presence of the $\mathrm{CH}_{3}$ or $\mathrm{Cl}$-substituents weakly affects on the peak positions on the characteristics IR-maxima of the compounds (1)-(7) (Fig. 1). The $\bar{v}_{\mathrm{NH}}$ and $\bar{v}_{\mathrm{C}=\mathrm{O}}$ stretching vibrations are affected about $11 \mathrm{~cm}^{-1}$ depending of the type of the substituens. In plane vibrations of the aromatic fragments within $1650-1450 \mathrm{~cm}^{-1}$ differ about $4 \mathrm{~cm}^{-1}$. These substituents significantly affect only the out-of-plane vibrations of the phenyl-fragments, observing within $800-600 \mathrm{~cm}^{-1}$ (Fig. 1). The application of the reducing-difference procedure of the $\bar{v}_{\mathrm{NH}}$ IR-band leads to strong reduction of corresponding $\bar{v}_{\mathrm{C}=\mathrm{O}}$ maximum, which is in accordance with the theoretical conformations (Scheme 2). The same is valid for the elimination of the out-of-plane vibrations of the aromatic fragments (Fig.2), at different dichroic ratio, which is also in accordance with the predicted and experimentally observed geometries of (1)-(7).

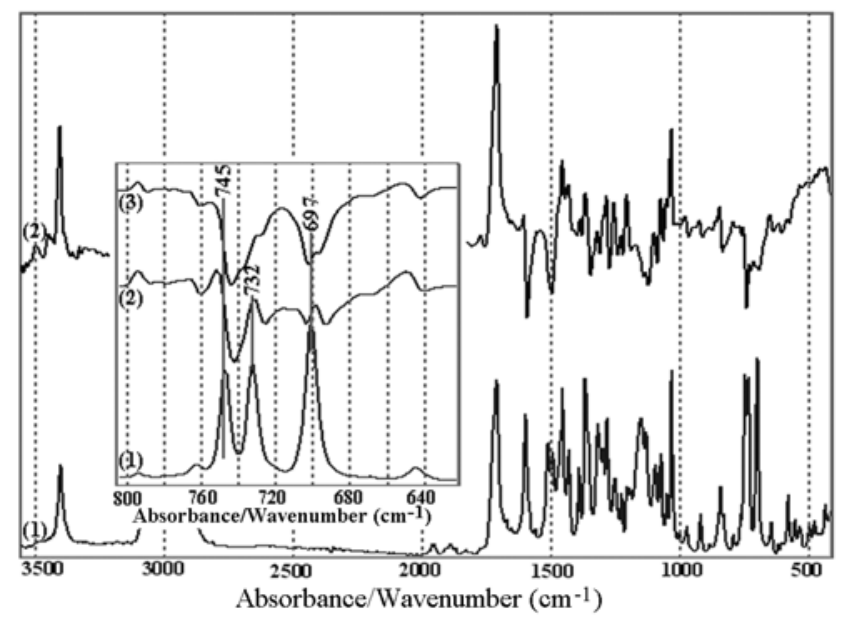

Figure 2. Non-polarized IR- (1) and difference IR-LD (2) spectra of (5); Small figure: Non-polarized IR-(1), difference (2) and reduced IR-LD (3) spectra after elimination the band at $732 \mathrm{~cm}^{-1}$ within $800-600$ $\mathrm{cm}^{-1}$ IR-region

The experimental electronic spectra of (1)-(7), depicted in Fig. 3, show the typical for the phenyl-systems UV-bands at about $210 \mathrm{~nm}\left(\varepsilon_{v}\right.$ about $\left.11000 \mathrm{~L} \cdot \mathrm{mol}^{-1} \mathrm{~cm}^{-1}\right)$ and at about $248 \mathrm{~nm}\left(\varepsilon_{v}\right.$ about $\left.2000 \mathrm{~L} \cdot \mathrm{mol}^{-1} \cdot \mathrm{cm}^{-1}\right)$ of the K- and
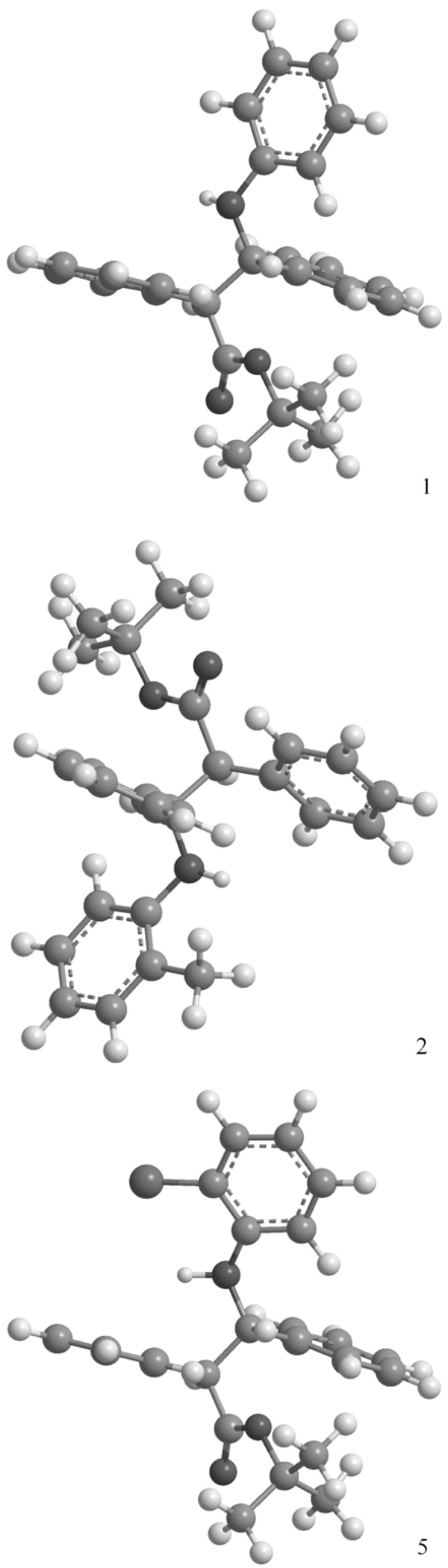

Scheme 2. The most stable conformers of (1), (2) and (5) 


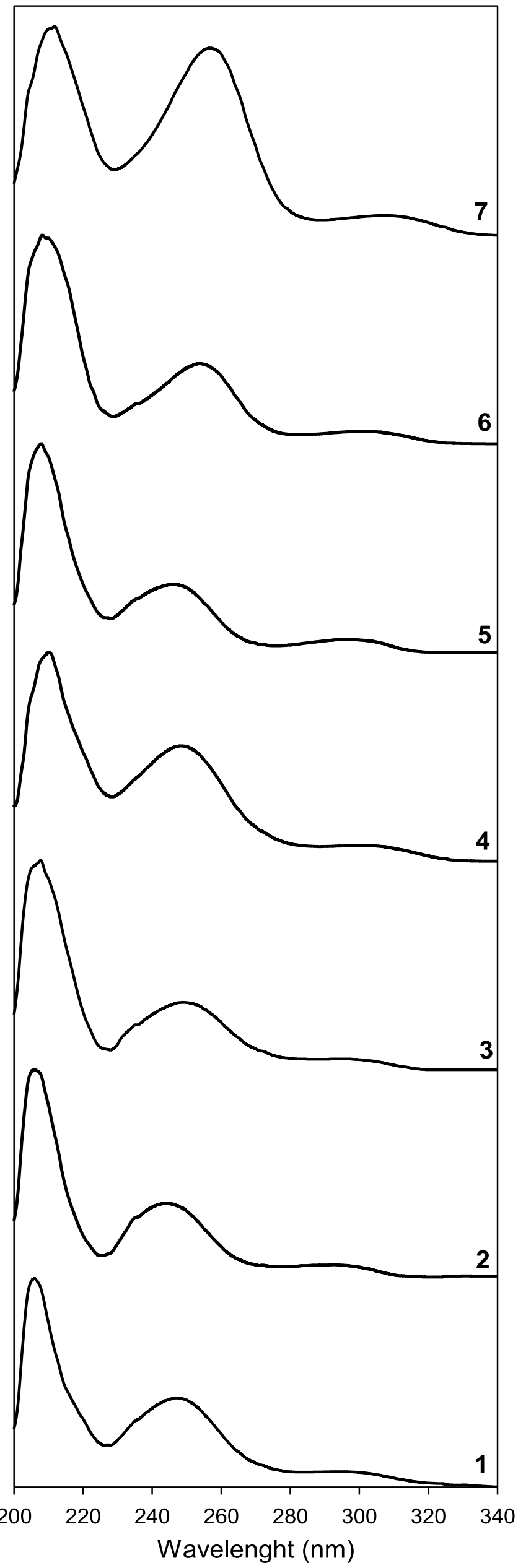

Figure 3. UV-spectra of (1)-(7) in ethanol solution at concentration $2.5 .10^{-5} \mathrm{M}$ and $0.921 \mathrm{~cm}$ quartz cell
B-bands. The intramolecular transfer leads to observation of the weak band about $300 \mathrm{~nm}$ with $\varepsilon_{v}$ about $1000 \mathrm{~L} \cdot \mathrm{mol}^{-1} \cdot \mathrm{cm}^{-1}$. The corresponding HOMO and LUMO MOs illustrate the origin of this UV-band in all of the compound (1)-(7). The distributions for the HOMO and LUMO of the lowest single excited state show the discussed optical absorption. These data are in accordance with the theoretically predicted UV-spectra in the same solvent (Table 1, Fig. 3). The presence of the $\mathrm{CH}_{3}$ - or Cl-substituents affects the UVmaxima about $10 \mathrm{~nm}$ and a hyperchromic effect of about $300 \mathrm{~L} \cdot \mathrm{mol}^{-1} \cdot \mathrm{cm}^{-1}$ of the B-bands is observed in the cases of corresponding derivatives (5)-(7), which could be explained with the presence of $\mathrm{Cl}$-substituent.
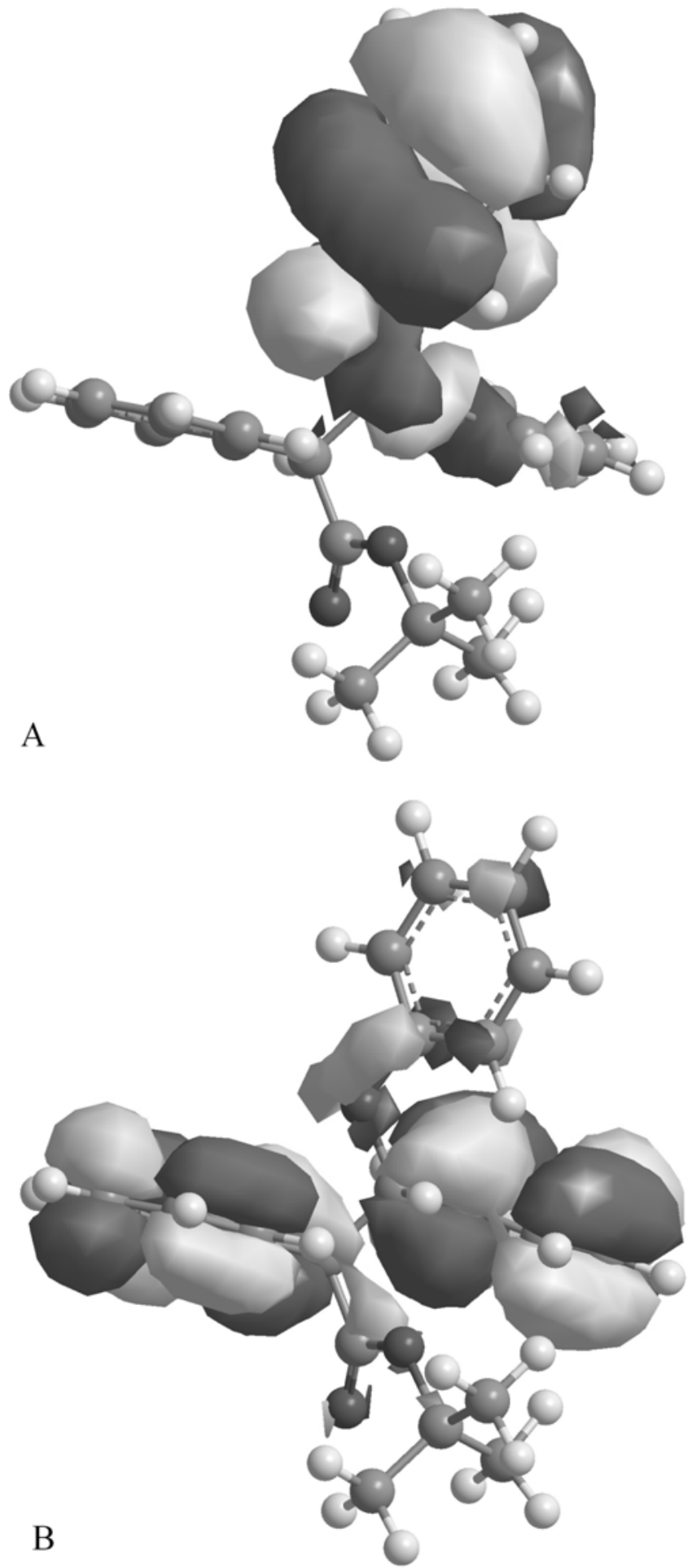

Scheme 3. HOMO (A) and LUMO (B) MOs of (1) 
Table 1. Theoretical and experimental UV-spectra of (1)-(7) in ethanol solution

\begin{tabular}{|c|c|c|c|c|c|c|c|}
\hline \multirow{2}{*}{ Compound } & (1) & (2) & (3) & (4) & (5) & (6) & $(7)$ \\
\hline & \multicolumn{7}{|c|}{$\lambda[\mathrm{nm}]$} \\
\hline \multirow{3}{*}{ Exp. } & 200 & 206 & 206 & 203 & 205 & 202 & 202 \\
\hline & 245 & 248 & 250 & 252 & 244 & 254 & 257 \\
\hline & 298 & 302 & 307 & 303 & 303 & 300 & 300 \\
\hline \multirow{3}{*}{ Theor. (f) } & $\begin{array}{l}187 \\
(0.2221) \\
\end{array}$ & $\begin{array}{l}193 \\
(0.1997) \\
\end{array}$ & $\begin{array}{l}189 \\
(0.1999) \\
\end{array}$ & $\begin{array}{l}187 \\
(0.2006) \\
\end{array}$ & $\begin{array}{l}200 \\
(0.2681) \\
\end{array}$ & $\begin{array}{l}202 \\
(0.2823) \\
\end{array}$ & $\begin{array}{l}202 \\
(0.2889) \\
\end{array}$ \\
\hline & $\begin{array}{l}240 \\
(0.1278)\end{array}$ & $\begin{array}{l}242 \\
(0.1200)\end{array}$ & $\begin{array}{l}244 \\
(0.1213)\end{array}$ & $\begin{array}{l}241 \\
(0.1218)\end{array}$ & $\begin{array}{l}240 \\
(0.1431)\end{array}$ & $\begin{array}{l}243 \\
(0.1318)\end{array}$ & $\begin{array}{l}241 \\
(0.1226)\end{array}$ \\
\hline & $\begin{array}{l}303 \\
(0.0067)\end{array}$ & $\begin{array}{l}303 \\
(0.0192)\end{array}$ & $\begin{array}{l}303 \\
(0.0141)\end{array}$ & $\begin{array}{l}303 \\
(0.0163)\end{array}$ & $\begin{array}{l}301 \\
(0.0101)\end{array}$ & $\begin{array}{l}300 \\
(0.0100)\end{array}$ & $\begin{array}{l}300 \\
(0.0103)\end{array}$ \\
\hline
\end{tabular}

\section{CONCLUSION}

The synthetic pathway for the obtaining of seven tertbutyl esters of 2,3-diaryl-3-arylaminopropanoic acids is reported, leading to the yields of $62-72 \%$. The compounds were isolated, spectroscopically and structurally determined by means of the polarized IR- and UV-spectroscopy and ${ }^{1} \mathrm{H}-\mathrm{NMR}$. The presence of methyl- or chlor- substituents weakly affects on the positions of the characteristic IR bands of the compounds studied. In the electronic spectra of the $\mathrm{Cl}$-containing compounds a hyperchromic effect is observed. Theoretical quantum chemical calculations are also performed with a view to supporting and explaining the corresponding electronic spectra in the solution.

\section{Acknowledgements}

The authors thank the Sofia University Scientific Fund and Dr. B. Ivanova (Institute of Environmental Research (INFU), TU Dortmund, Germany).

\section{LITERATURE CITED}

1. Drey, C.N. (1985). In Barret G. S. (Ed.), Chemistry and Biochemistry of the Amino Acids (1 st ed.), London, Chapman \& Hall.

2. Liu, M. \& Sibi, M. (2002). Recent advances in the stereoselective synthesis of $ß$-amino acids. Tetrahedron 58(40), 7991-8035. DOI: 10.1016/S0040-4020(02)00991-2.

3. Periasamy, M., Suresh, S. \& Ganesan, S. (2005). Stereoselective synthesis of syn- $\beta$-amino esters using the $\mathrm{TiCl}_{4} /$ $\mathrm{R}_{3} \mathrm{~N}$ reagent system. Tetrahedron Lett. 46(33), 5521-5524. DOI:10.1016/j.tetlet.2005.06.048.

4. Krauthauser, S., Christianson, L., Powell, D. \& Gellman, S. (1997). Antiparallel sheet formation in B-peptide foldamers: Effects of $B$-amino acid substitution on conformational preference. J. Am. Chem. Soc. 119(48), 11719-11720. DOI: 10.1021/ ja9730627.

5. Kise, N., Ueda, N. (1999). A new method for the synthesis of $\beta$-amino acid derivatives and B-lactams. Reaction of $\mathrm{N}$-alkoxycarbonyl-1-methoxyamines with esters. J. Org. Chem. 64(20), 7511-7514. DOI: 10.1021/jo990821q.

6. Escalante, J., Guanzales-Tototzin, M., Avina, J., MinozMiniz, O. \& Juaristi, E. (2001). Synthesis of B-lactams and cyclo- $\beta$-dipeptides from $\beta$-amino acids: experimental observations and theoretical analysis. Tetrahedron, 57(10), 1883-1890. DOI:10.1016/S0040-4020(00)01169-8.

7. Taggi, A., Havez, A. \& Lectka, T. (2003). $\alpha$-Imino esters: Versatile substrates for the catalytic, asymmetric synthesis of $\alpha$ - and $\beta$-amino acids and B-lactams. Acc. Chem. Res. 36(1), 10-19. DOI: 10.1021/ar020137p.

8. Rosenblum, S., Huynh, T., Afonso, A., Davis, H., Yumibe, N., Clader, J. \& Burnett, D. (1998). Discovery of 1-(4Fluorophenyl)-(3R)-[3-(4-fluorophenyl)-(3S)-hydroxypropyl](4S)-(4-hydroxyphenyl)-2-azetidinone ( $\mathrm{SCH} 58235)$ : A De- signed, Potent, Orally Active Inhibitor of Cholesterol Absorption. J. Med. Chem. 41(6), 973-980. DOI: 10.1021/jm970701f.

9. Koleva, B., Kolev, T., Seidel, R., Spiteller, M., MayerFigge, H. \& Sheldrick, W. (2009). Self-assembly of hydrogensquarates: Crystal structures and properties. J. Phys. Chem. A 113(13), 3088-3095. DOI: 10.1021/jp8106233.

10. Koleva, B., Kolev, T., Seidel, R., Mayer-Figge, H., Spiteller, M. \& Sheldrick, W. (2008). On the origin of the color in the solid state. Crystal structure and optical and magnetic properties of 4-Cyanopyridinium hydrogensquarate monohydrate. J. Phys. Chem. A. 112(13), 2899-2905. DOI: 10.1021/jp710765v.

11. Koleva, B.B, Kolev, T.M., Simeonov, V., Spassov, T. \& Spiteller, M. (2008) Linearly polarized IR-spectroscopy of partially oriented solids as a colloid suspension in nematic host: A tool for spectroscopic and structural elucidation of the embedded chemicals. J. Incl. Phen. Macro. 61, 319-333. DOI: $10.1007 / \mathrm{s} 10847-008-9425-5$.

12. Koleva, B.B., Kolev, T., Mayer-Figge, H., Seidel, R.W., Spiteller, M. \& Sheldrick, W.S. (2008) Are there preferable conformations of the tryptammonium cation in the solid state? Crystal structure and solid-state linear polarized IRspectroscopic study of tryptammonium hydrogentartarate Struct. Chem. 19, 147-154. DOI: 10.1007/s11224-007-9265-8.

13. Ivanova, B. \& Spiteller, M. (2010). Noncentrosymmetric crystals with marked nonlinear optical properties. J. Phys. Chem. A. 114(15), 5099-5103. DOI: 10.1021/jp1002758.

14. Ivanova, B. \& Spiteller, M. (2010). Possible application of the organic barbiturates as NLO materials. Cryst. Growth Des. 10(6), 2470-2474. DOI: 10.1021/cg100284r.

15. Kolev, T., Koleva, B., Seidel, R., Spiteller, M. \& Sheldrick, W. (2009). New aspects on the origin of color in the solid state. Coherently shifting of the protons in violurate crystals. Cryst. Growth Des. 9(8), 3348-3352. DOI: 10.1021/cg900188k.

16. Ivanova, B. \& Spiteller, M. (2010). Conformations and properties of the L-tryptophyl-containing peptides in solution, depending on the $\mathrm{pH}$-theoretical study vs. experiments. Biopolymers 93(8), 727-734. DOI: 10.1002/bip.21437.

17. Ivanova, B. \& Spiteller, M. (2010). Organic mandelates as promising materials with non-linear optical application. Struct. Chem. 21(5), 989-993. DOI 10.1007/s11224-010-9635-5.

18. Frisch, M.J. Trucks, G.W. Schlegel, H.B., Scuseria, G.E., Robb, M.A., Cheeseman, J.R., Zakrzewski, V.G., Montgomery Jr., J.A., Stratmann, R.E., Burant, J.C., Dapprich, S., Millam, J.M.; Daniels, A.D., Kudin, K.N., Strain, M.C., Farkas, Ö., Tomasi, J., Barone, V., Cossi, M., Cammi, R., Mennucci, B., Pomelli, C., Adamo, C., Clifford, S., Ochterski, J., Petersson, G. A., Ayala, P.Y., Cui, Q., Morokuma, K., Salvador, P., Dannenberg, J.J., Malick, D. K., Rabuck, A. D., Raghavachari, K., Foresman, J. B., Cioslowski, J., Ortiz, J.V., Baboul, A. G., Stefanov, B.B., Liu, G.; Liashenko, A., Piskorz, P., Komáromi, I., Gomperts, R., Martin, R.L., Fox, D.J., Keith, T., Al-Laham, M.A., Peng, C. Y., Nanayakkara, A., Challacombe, M., Gill, P.M.W., Johnson, B., Chen, W., Wong, M.W., Andres, J.L., 
Gonzalez, C., Head-Gordon, M., Replogle, E. S. \& Pople, J. A. Gaussian 98, Gaussian, Inc., Pittsburgh, PA, 1998.

19. Dalton 2.0 Program Package, http://www.kjemi.uio.no/ software/dalton/dalton.html.

20. Becke, A.D. (1993). Density-functional thermochemistry. III. The role of exact exchange. J. Chem. Phys. 98(7), 56485652. DOI: 10.1063/1.464913.

21. Becke, A.D. (1996). Density-functional thermochemistry. IV. A new dynamical correlation functional and implications for exact-exchange mixing. J. Chem. Phys. 104(3), 10401046. DOI:10.1063/1.470829.

22. Lee, C., Yang, W. \& Parr, R.G. (1988). Development of the Colle-Salvetti correlation-energy formula into a functional of the electron density. Phys. Rev. B 37(2), 785-789. DOI: 10.1103/PhysRevB.37.785.

23. Scott, P. \& Radom, L. (1996). Harmonic Vibrational Frequencies: An Evaluation of Hartree-Fock, Moller-Plesset, Quadratic Configuration Interaction, Density Functional Theory, and Semiempirical Scale Factors. J. Phys. Chem. 100(41), 16502-16513. DOI: 10.1021/jp960976r.

24. DeFrees D.J. \& McLean, A.D. (1985). Molecular orbital predictions of the vibrational frequencies of some molecular ions. J. Chem. Phys. 82(1), 333-341. DOI:10.1063/1.448805.

25. Dryanska, V.D., Tasheva, D.N. \& Ivanov, Ch.Ch. (1992). Phase transfer catalyzed additions IX. Influence of the reaction conditions on the reaction of tert-butyl phenylacetate with benzylideneaniline. Bulg. Chem. Commun. 26(1), 66-73.

26. Spassov, S.L. (1971). Nuclear magnetic resonance spectra, configuration and conformation of diastereomers-II: Ethyl esters of 3-substituted 2,3-diphenylpropanoic acids: Magnetic nonequivalence induced by two asymmetric centres. Tetrahedron 27(6), 1323-1329. DOI:10.1016/S0040-4020(01)90883-X.

27. Kolev, T., Preut, H., Bleckmann, P. \& Juchnovski, I. (1995). (+/-)-Threo-3-Hydroxy-2,3-diphenylpropanoic acid methyl ester Acta Crystallogr. C. 51, 1350-1352. DOI:10.1107/ S0108270194014277.

28. Kolev, T., Preut, H., Bleckmann, P. \& Juchnovski, I. (1995). (+/-)-Threo-3-Hydroxy-2,3-diphenylpropanoic acid dimethylamide. Acta Crystallogr. C. 51, 1169-1170. DOI:10.1107/ S0108270194014666. 